Sains Malaysiana 47(4)(2018): 763-771

http://dx.doi.org/10.17576/jsm-2018-4704-15

\title{
Interface Pressure of Lycra Orthosis at Different Postures in Children with Cerebral Palsy (CP)
}

(Tekanan Antara Muka Likra Ortosis untuk Postur Berbeza pada Kanak-kanak Palsi Serebrum (CP))

\author{
IDA HASNi SHAARI, NoOR AZUAN ABU OSMAN* \& HANIE NADIA SHASMIN
}

\begin{abstract}
Medical compression garment functions by exerted interface pressure between the fabric and skin. Yet, none of the previous studies have determine the pressure level of Lycra based orthosis. The current work aimed to determine the pressure level of Lycra orthosis at different postures in children with CP. Five (5) children with CP were recruited. Each were given a custom made Lycra orthosis. Two Tekscan medical sensor were placed over lateral side of upper garment and pants. The pressure was recorded when the child was in sitting, sit-to-stand (STS) and standing postures. There are significant differences of the interface pressure between each children, at different postures. The highest pressure recorded over upper garment is $122 \mathrm{mmHg}$ and $120 \mathrm{mmHg}$ over pants, both during sitting position. Overall, the Lycra orthosis exerted highest pressure over top garments than pants during sitting position.
\end{abstract}

Keywords: Interface pressure; lycra; orthosis; posture; rehabilitation

ABSTRAK

Pakaian mampatan perubatan berfungsi dengan memberikan tekanan antara muka antara fabrik dan kulit. Namun, tiada kajian terdahulu yang mengenal pasti tahap tekanan Likra berasaskan ortosis ini. Kertas ini bertujuan untuk mengenal pasti tahap tekanan Likra ortosis untuk postur berbeza pada kanak-kanak dengan CP. Lima (5) orang kanak-kanak dengan CP telah dipilih. Setiap seorang telah diberikan Likra ortosis yang dijahit tempah. Dua penderia perubatan Tekscan telah diletakkan pada sisian bahagian atas pakaian dan seluar. Tekanan direkodkan semasa kanak-kanak itu berada pada postur duduk, duduk untuk berdiri (STS) dan berdiri. Terdapat perbezaan yang signifikan pada tekanan antara muka antara kanak-kanak, pada postur yang berbeza. Tekanan paling tinggi yang direkodkan pada pakaian adalah $122 \mathrm{mmHg}$ dan $120 \mathrm{mmHg}$ pada seluar, kedua-duanya pada posisi duduk. Secara keseluruhannya, Likra orthosis memberikan tekanan tinggi pada pakaian daripada seluar dalam posisi duduk.

Kata kunci: Likra; ortosis; pemulihan; postur; tekanan antara muka

\section{INTRODUCTION}

Lycra based orthosis has been used more than ten years to provide structural correction over mal-alignment posture and improves functional abilities mainly in patient with neurological deficits like adults with stroke and children with cerebral palsy (CP) (Charlton 2015; Elliott et al. 2011; Mohapatra et al. 2015; Sau-Fun et al. 2011). The Lycra based orthosis functions by producing interface pressure over the patient's limbs or body segment. The interface pressure is expected to hold the limbs while patient in static or dynamic posture. Some of the studies reported on reduction in muscles spasticity and improved proximal segments stability when their patient is wearing the Lycra based orthosis (Matthews et al. 2016; Morris et al. 2011; Rennie et al. 2000).

Compared to the other medical compression product, the products interface pressure were determined and guided by Laplace's Law or reduction factors. Laplace's law is related to the textile tensile properties and body or limbs circumference (Wang et al. 2011). The law has predicted that the pressure will decrease inversely when the limb circumference increases. The functions of medical compression product such as medical compression socks are strongly related to Laplace's Law because such products were expected to reduce oedema and improve circulation. Meanwhile, reduction formulas are commonly applied for burn compression garment. The patient's measurement was reduced by $10 \%, 15 \%$ or $20 \%$ to construct the garment (Macintyre \& Baird 2006). The reduction will help to reduce the oedema due to burn and it provides consistent and gradient pressure from proximal to distal region to improve limb's circulation.

Other than that, Lycra based orthosis is expected to exert continuous and even pressure over the targeted limbs or body segment. This is because the orthosis is supposed to hold the limbs or body segment while the child is not in a static position. At the same time, the pressure is supposed to work against the spastic muscles, thus reducing the spasticity. Consequently, providing stability to the child's body segment, mainly during upright posture. However, 
none of the information about the pressure level exerted by Lycra based orthosis is proven. As being determined in other medical products, it is also important to show the level of interface pressure exerted by Lycra based orthosis. Not only to provide evidence on how the orthosis works, but also to ensure that the orthosis can be safely used (Abd El-Kafy et al. 2014; Bahramizadeh et al. 2015; Elliott et al. 2011; Jin et al. 2013). Therefore, the aim of the current study was to identify the interface pressure of Lycra Orthosis on children with cerebral palsy (CP) during static and dynamic postures.

\section{METHODS}

This study has been approved by the Medical Ethics Committee of University Malaya Medical Centre (UMMC), Kuala Lumpur Malaysia.

\section{LYCRA ORTHOSIS PREPARATION}

The orthosis is made from Lycra satin net, which is available at UMMC occupational therapy department. The orthosis was constructed by experience paediatric occupational therapists and orthotists with 20 years of experience. The orthosis has separate top garment and pants (Figure 1). The top garment is equipped with bilateral double layer straps, and the pants is made up of single layer of Lycra fabric with a pair of side straps at the pelvic region level.

\section{SUBJECTS’ RECRUITMENT}

A total of five children with spastic diplegia were recruited for this study as shown in Table 1 . The children were recruited from The Spastic Children's Association of
Selangor and Federal Territory as well as from Malaysian Advocates for Cerebral Palsy (MyCP).

Inform consent was signed by their parents after they have understood the purpose of this study and willing to participate.

Only children from the age of 4 to 15 years old were included in this study. They need at least to be able to sit in an upright position without back support, be able to walk and stand with or without assistant, be able to count one to ten and able to understand instructions. Both child and parents need to be able to communicate in English. Only child with Gross Motor Functional Scale (GMFCS) level I, II and III, as assessed by experience physiotherapist (10 $\geq$ years' experiences), were included.

Children with medical problems like asthma, seizures and heart problem (Confirmed by Rehabilitation physician) and skin problems such as eczema (confirmed by Rehabilitation physician) were excluded from the study. Those who had received any Botulinum injection in the lower extremities or upper limbs for the past 12 months, any lower extremity serial casting for the past 12 months, have severe postural scoliosis and structural scoliosis, confirmed by x-ray investigation, have tendon Achilles tightness; foot is not in plate grade when standing, have hip and knee flexion contractures of more than 10 degrees, have severe musculoskeletal problems (e.g. hip dislocation) and have muscle tone on the Modified Ashworth Scale of $3 \geq$ at any upper and lower extremities were also excluded.

\section{SIT-TO-STAND (STS) DURATION AND TRUNK CONTROL ASSESSMENT}

Prior to interface pressure analysis, the child's performed one STS motion and the duration was recorded with and
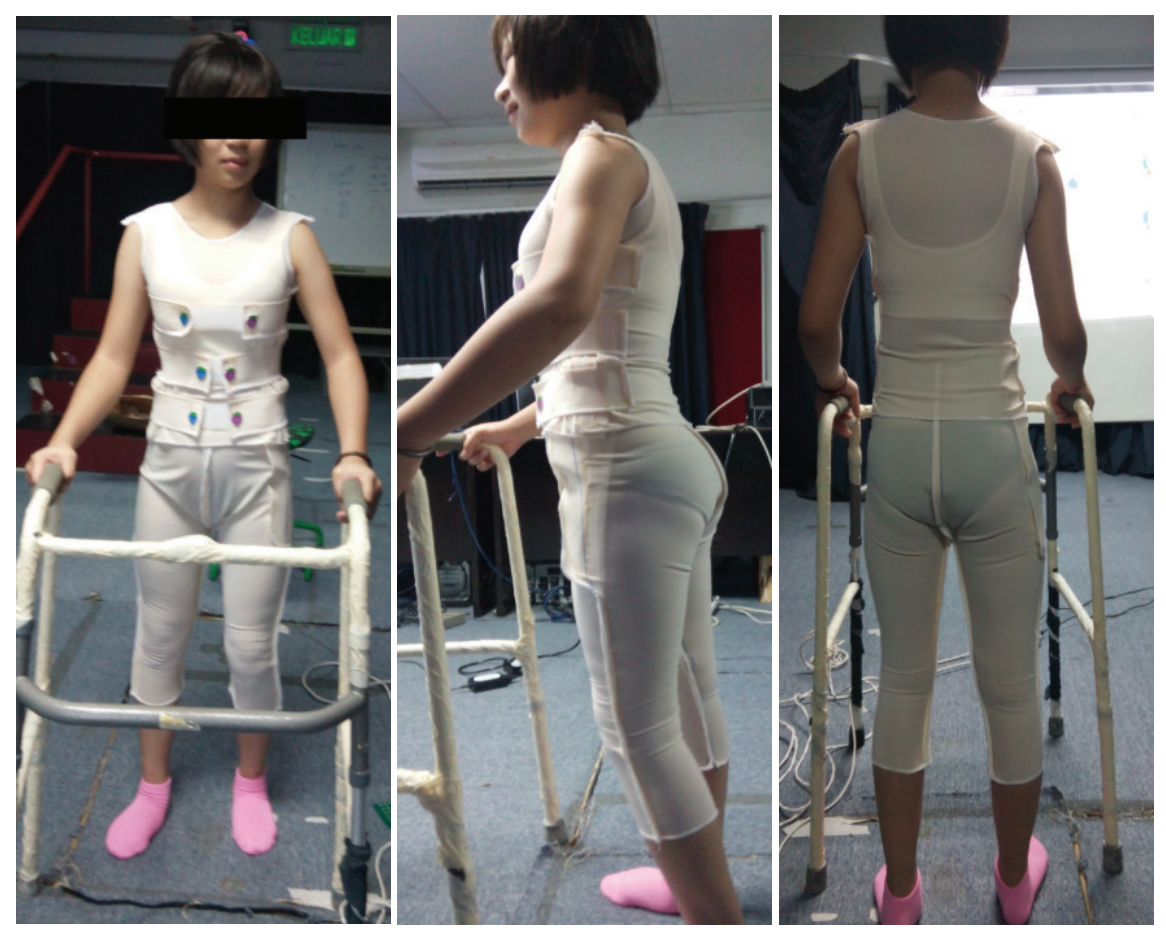

FIGURE 1. Upper garment and pant of Lycra orthosis 
TABLE 1. Subject's demographic and physical characteristics

\begin{tabular}{ccccccc}
\hline & & Child 1 & Child 2 & Child 3 & Child 4 & Child 5 \\
\hline & Gender/Age (years old) & Boy/ 13 & Girl/14 & Girl /15 & Girl/ 10 & Boy/11 \\
\hline GMFCS scale & III & II & III & II & II \\
\hline Body weight $(\mathrm{kg}) /$ Height $(\mathrm{cm})$ & $25 / 132$ & $30 / 147$ & $38 / 142$ & $22 / 118$ & $35 / 160$ \\
\multirow{2}{*}{ Trunk } & Body dimension (cm) & & & & & \\
& Axillary circumference & 71.5 & 65.5 & 78 & 50 & 62 \\
& Xiphoid circumference & 64 & 58.5 & 74 & 55 & 58 \\
& Umbilical circumference & 59 & 50.5 & 64 & 50.5 & 49 \\
\hline \multirow{2}{*}{ Thigh } & Groin circumference & 41 & 35.5 & 39.5 & 32 & 37 \\
& 10cm below groin circumference & 34 & 29 & 33.5 & 32.5 & 31.2 \\
& 20cm below groin circumference & 33 & 25 & 32.5 & 22 & 27 \\
\hline
\end{tabular}

without orthosis. Trunk Control Measurement Scale (TCMS) was used to determine each child's trunk control ability with and without orthosis.

\section{INTERFACE PRESSURE ANALYSIS}

A pair of Medical Sensor 9811E (TEKSCAN) was calibrated using Tekscan Pressure Mapping System, at 10-50 kPa, (based on patient's body weight) with $10 \mathrm{~Hz}$ frequency prior to the experiment. Figure 2 shows the sensor calibration graph before and after the experiment. The graph indicates that the sensitivity of the sensor is reducing after experiment.

Both sensors were placed over the lateral side of participant's trunk and thigh (Figure 3). The pressure sensor was first placed over the participant's thigh. Preanalysis pressure was identified for both sensors prior to analysis. This is to ensure that both sensors are well function. Three min after the placement over bilateral thigh, the baseline interface-pressure was recorded in sitting position. The pressure was then recorded for $500 \mathrm{~s}$ at $10 \mathrm{~Hz}$. Next, the pressure was recorded when the child is performing the sit-to-stand activity. The child performed six trials of sit-to-stand. As the child reached the six $\left(6^{\text {th }}\right)$ standing position, the pressure was recorded in standing position. Participant blood pressure, oxygen level and

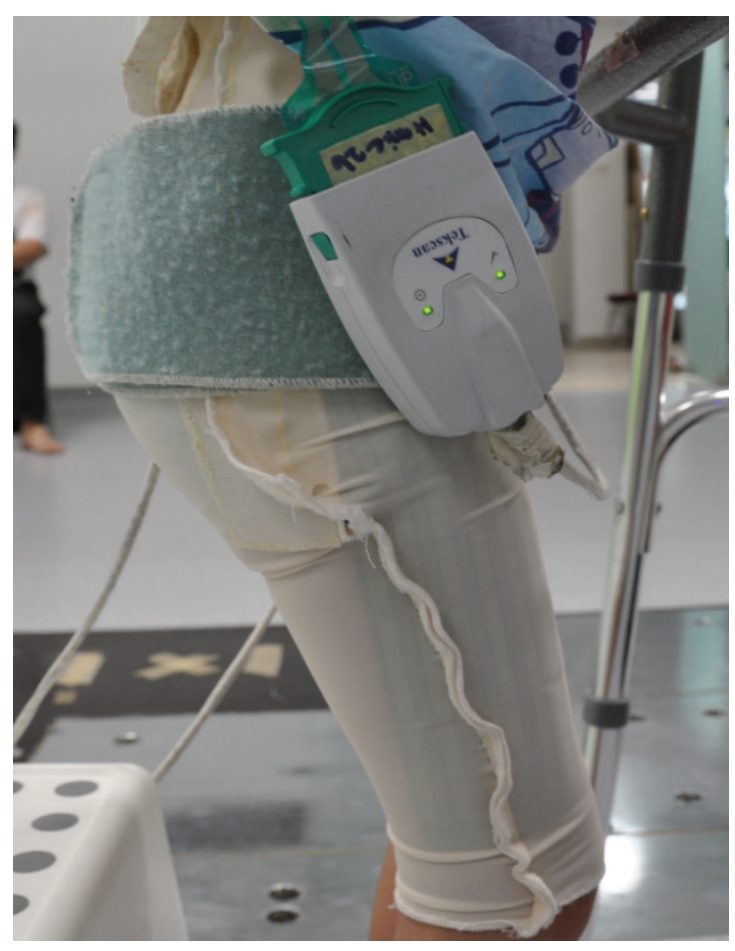

FIGURE 3. Placement for Medical Sensor 9811E (TEKSCAN) over subject's pant

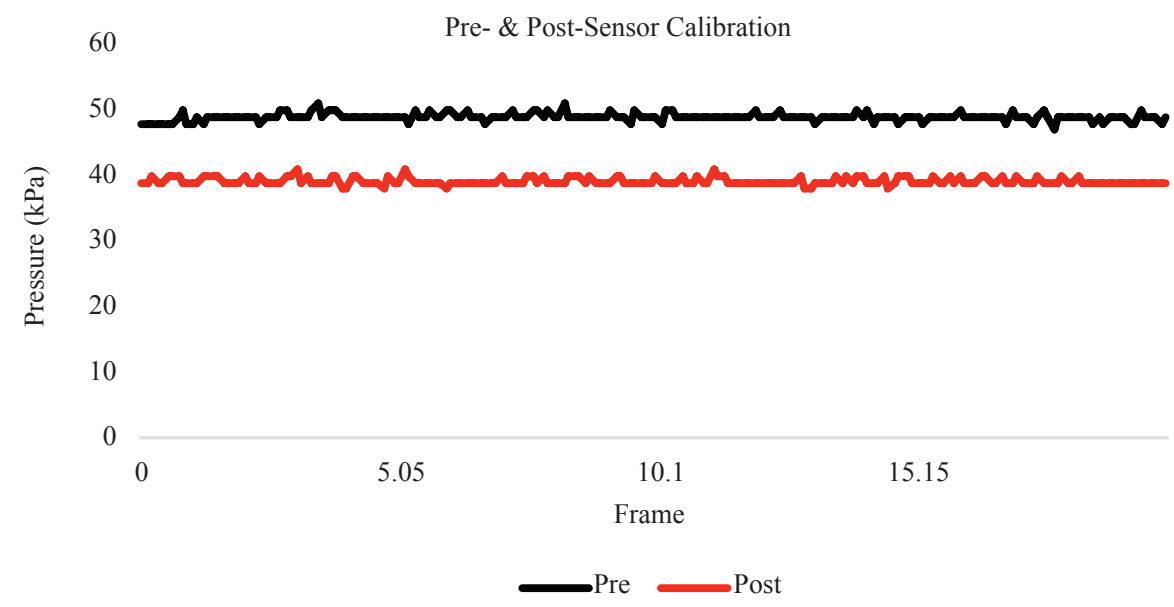

FIGURE 2. Pre- and post-sensor calibration 
respiratory rate were monitored throughout the analysis. Next, both sensors were placed over the lateral side of patient's trunk and the same activity was repeated.

\section{STATISTICAL ANALYSIS FOR ORTHOSIS INTERFACE PRESSURE}

For the data analysis, the mean and standard deviation for both sensors in all positions were identified. Data normality test was performed. The data seems to be not normally distributed. Thus, all non-parametric test was performed for the analysis. T-test was used to determine the differences between pressure exerted by top garment and pant, in each child. Interface pressure differences in each position were evaluated using Kruskal-Wallis test, for each child. The significant level was set at 0.05 . All statistical analysis was performed using SPSS version 16.

\section{RESULTS}

\section{STS DURATION AND TCMS SCORE}

Table 2 shows the duration and trunk control scores of the situation and duration of the child with and without the existence of Lycra. Greatest duration changes was seen on child 4, with the improvement of 1.79 s. For trunk control, child 3 showed marked changes on the TCMS score, with 10 points differences between STS with and without the existence of Lycra.

TABLE 2. Subject's STS duration and trunk control score without and -with Lycra orthosis

\begin{tabular}{ccccc}
\hline \multirow{2}{*}{ Subject } & \multicolumn{2}{c}{ 1 STS Duration (s) } & \multicolumn{2}{c}{ TCMS (/58) } \\
\cline { 2 - 5 } & w/out & With & w/out & With \\
& Lycra & Lycra & Lycra & Lycr \\
\hline Child 1 & 2.60 & 2.43 & 45 & 46 \\
Child 2 & 2.53 & 2.49 & 37 & 42 \\
Child 3 & 3.63 & 3.35 & 30 & 40 \\
Child 4 & 3.74 & 1.95 & 29 & 34 \\
Child 5 & 2.67 & 2.52 & 30 & 36 \\
\hline
\end{tabular}

\section{EFFECTS BODY DIMENSION ON ORTHOSIS INTERFACE PRESSURE}

Tables 3 and 4 show the interface pressure range produced by each child's orthosis over trunk and pelvisthigh segments. The t-test analysis indicates significant differences between interface pressure produce over top garment and pant $(p<0.05)$ in each child orthosis. The mean pressure was found to be greater over top garment than pant in each children.

Figure 4 shows the interface pressure $(\mathrm{mmHg})$ of the orthosis at child's trunk and pelvic segment in sitting position. At axillary level, the highest interface pressure (mean) is produced by Child 1 garment $(122 \pm 1.5)$ and the lowest pressure is exerted by Child 4 and Child 5 garment (12.8 $\pm 1.8 / 13.7 \pm 3.1)$, at umbilical level. Overall, it was
TABLE 3. The orthosis interface pressure range, over child's trunk segment

\begin{tabular}{lcccc}
\hline \multicolumn{5}{c}{ Trunk } \\
\hline & $\begin{array}{c}\text { Body } \\
\text { dimension } \\
(\mathrm{cm})\end{array}$ & \multicolumn{2}{c}{ Interface pressure $(\mathrm{mmHg})$} \\
\cline { 3 - 5 } & Sitting & STS & Standing \\
\hline Child 1 & $59-71.5$ & $48-122$ & $11-33$ & $11-51$ \\
Child 2 & $50.5-65.5$ & $17-60$ & $2-26$ & $9-35$ \\
Child 3 & $64-78$ & $16-37$ & $5-8$ & $15-38$ \\
Child 4 & $50-55.5$ & $13-80$ & $9-47$ & $6-46$ \\
Child 5 & $49-62$ & $14-27$ & $13-21$ & $9-26$ \\
\hline
\end{tabular}

TABLE 4. The orthosis interface pressure range, over child's pelvis-thighs segment

\begin{tabular}{lcccc}
\hline \multicolumn{5}{c}{ Pelvis-thighs } \\
\hline & $\begin{array}{c}\text { Body } \\
\text { dimension } \\
(\mathrm{cm})\end{array}$ & \multicolumn{2}{c}{ Interface pressure $(\mathrm{mmHg})$} \\
\cline { 3 - 5 } & Sitting & STS & Standing \\
\hline Child 1 & $33-41$ & $70-120$ & $33-91$ & $15-47$ \\
Child 2 & $25-35.5$ & $22-74$ & $6-45$ & $3-47$ \\
Child 3 & $32.5-39.5$ & $12-24$ & $8-24$ & $9-22$ \\
Child 4 & $22-32.5$ & $3-66$ & $2-17$ & $2-13$ \\
Child 5 & $27-37$ & $14-34$ & $11-22$ & $8-19$ \\
\hline
\end{tabular}

found that the pressure is consistently greater in Child 1 garment at all trunks level. The orthosis highest pressure

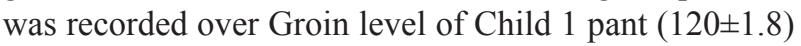
and the least pressure was recorded over Child 4 pant $(2.9 \pm 2.4)$ at $20 \mathrm{~cm}$ below groin level. Overall, the pants interface pressure was found to be higher in Child 1 pant compared to the other children.

During STS, for trunk segment, the highest interface pressure was produced at axillary level by Child 4 garment $(46.9 \pm 12.4)$ and the lowest pressure was recorded in Child 2 garment (1.7 \pm 5 ) at xiphoid level (Figure 5). At thighs segment, the highest interface pressure recorded was over Child 1 groin level $(90.8 \pm 42.4)$ and the lowest pressure recorded was in Child 4 garment $(1.9 \pm 2.6)$ at $20 \mathrm{~cm}$ below groin level.

The garment interface pressure during standing position, was found to be higher at axillary level of Child 1 garment (50.5 \pm 37.4$)$ and the lowest were found at Child $4(6.5 \pm 3.5)$ umbilical level. Meanwhile at thighs segment, the highest interface pressure at Groin level is recorded at Child 1 garment $(46.8 \pm 8.8)$ and the lowest pressure is recorded at Child $4(2.8 \pm 3), 20 \mathrm{~cm}$ below groin level (Figure 6).

The Friedman test indicate significant different on the orthosis interface pressure at trunk and thigh segment during sitting, STS and standing in all subject $(p<0.05)$.

\section{ORTHOSIS INTERFACE PRESSURE RANGE AT DIFFERENT POSTURES}

Overall, the results showed that most of the orthosis interface pressure was higher when these children were 


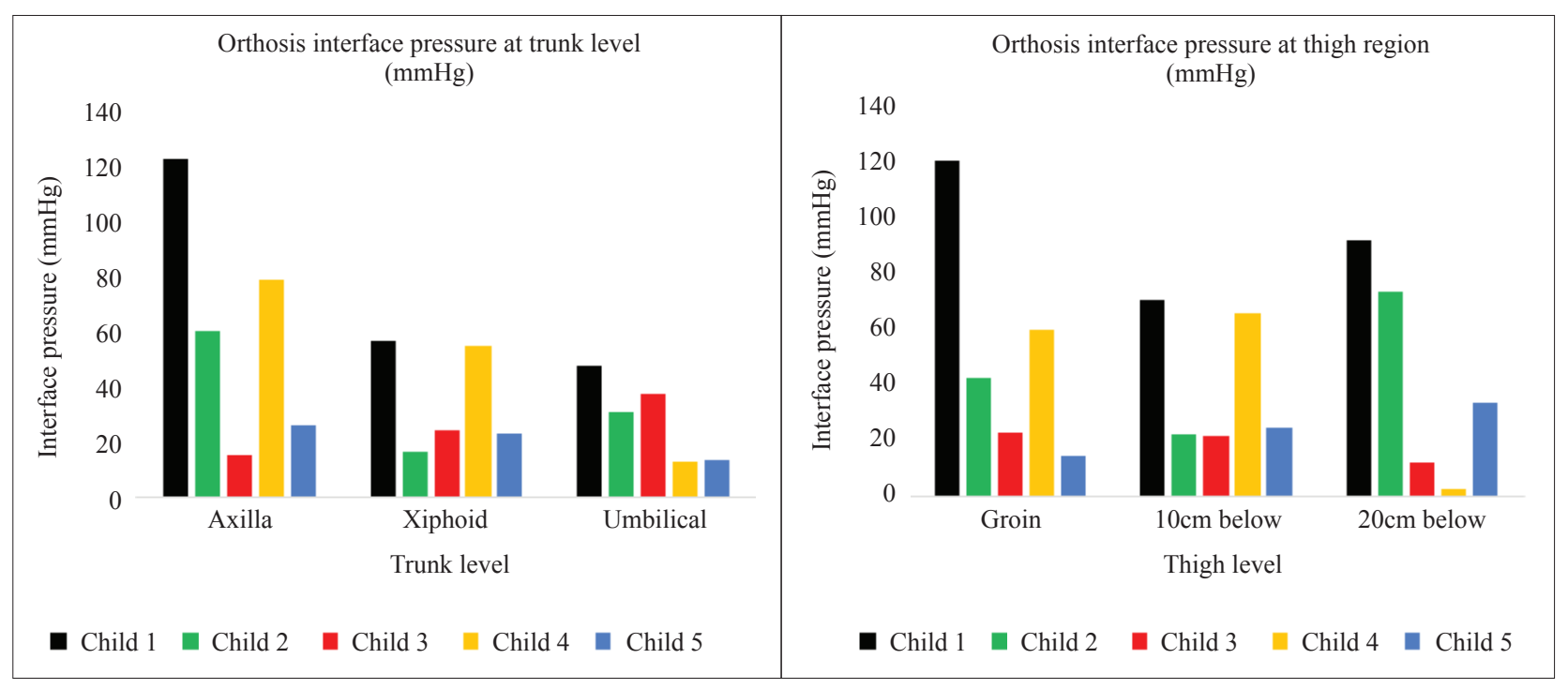

FIGURE 4. Garment interface pressure $(\mathrm{mmHg})$ at trunk and pelvic segment during sitting

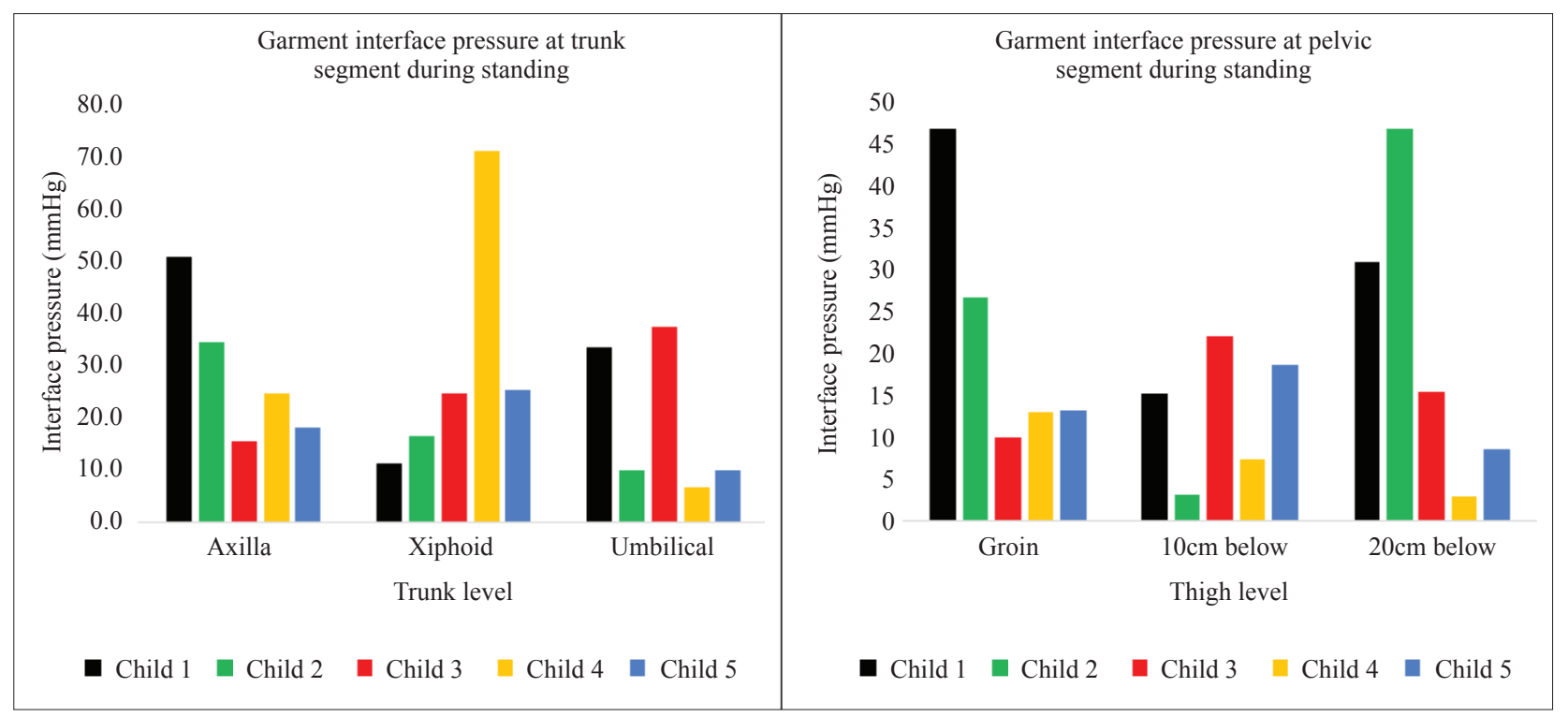

FIGURE 5. Garment interface pressure $(\mathrm{mmHg})$ at trunk and pelvic segment during STS

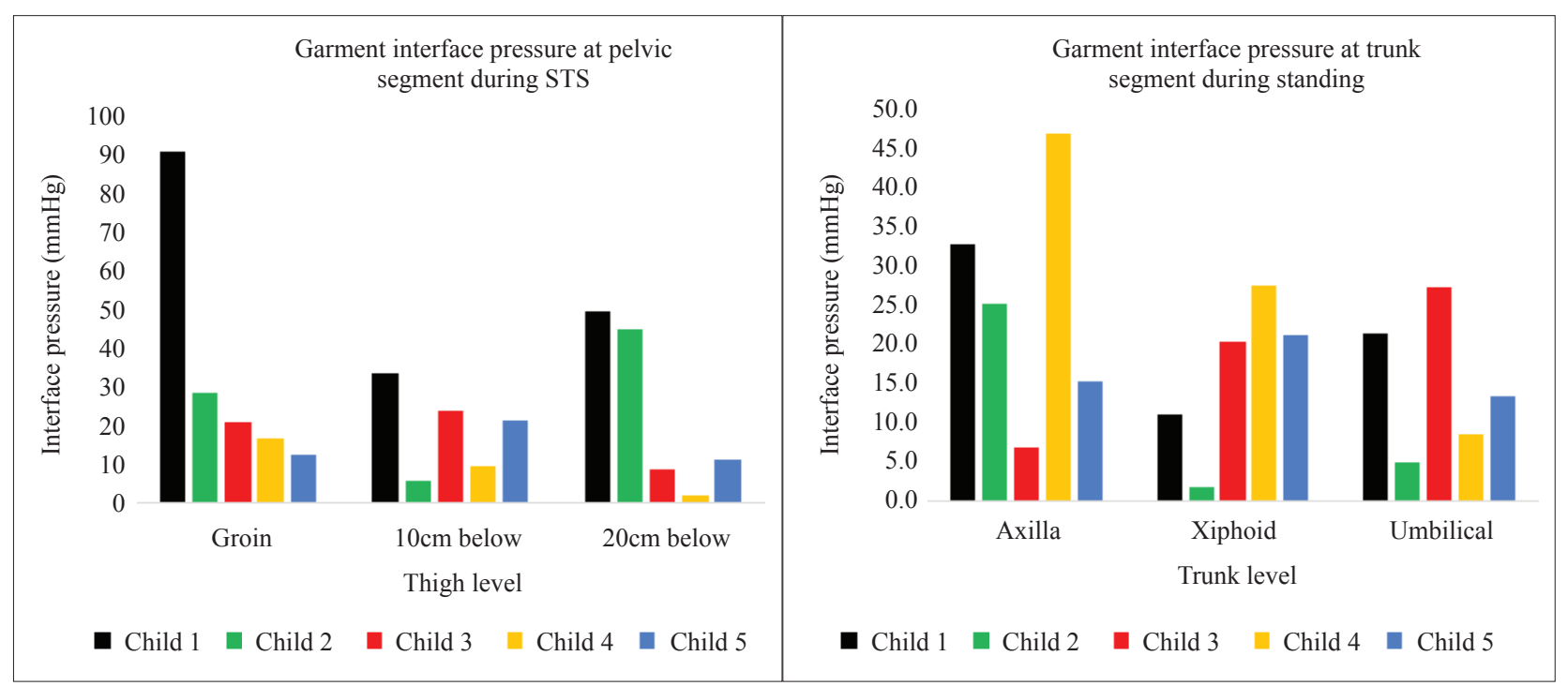

FIGURE 6. Garment interface pressure $(\mathrm{mmHg})$ at trunk and pelvic segment during standing 
in sitting position (Tables 3 and 4). The interface pressure was found to be the lowest when the child is performing STS activity. These patterns were found to be consistent in all children.

\section{DISCUSSION}

The Lycra orthosis (LO) is a dynamic fitted, soft orthosis made from Lycra power net fabric. Like other medical compression products, the current orthosis functions by exerting interface pressure onto specific body region, in the current study, trunk and thighs segments. Therefore, it is important to ensure the exerted pressure serves the function of orthosis; at the same time comfortable and can be safely used (Wang \& Zhang 2013). An inappropriate interfacepressure may affect the child's motivation, comfort, posture, movement, and health. Insufficient pressure may cause inefficiency of the orthosis and probably reduces the child and parents interest towards the orthosis. Whereas, greater pressure perhaps might endanger the child's physical health, interrupt circulations, cause fatigue, reduce heart and lung functions and even can cause other serious health complications (Wang et al. 2014).

\section{THE EFFECTS OF LO THE CHILD'S PHYSICAL ABILITY}

The LO are found to be clinically beneficial in the current study by improving trunk and pelvis movement, during STS in children with CP. This is based on the improvement on the child's STS duration and trunk control score. The available research findings show that the compression provided by medical compression products do help in improving performances, reduces muscle activities and reduces muscles vibration (Duffield et al. 2010; Higgin et al. 2009). Hence, there are possibilities that the improvement on the child's STS duration and trunk control score is related to the spasticity reduction and improvement of the segmental stability.

The exerted pressure may at the same time reduces the spasticity and provides segmental stability when the children is wearing it. This is based on the improvements on the child's trunk control score and STS duration. As mentioned earlier in the introduction, few studies indicate that there are fewer muscles activation occurred during running process when an athlete is wearing a compression garment (Troynikov et al. 2013; Wang et al. 2013). Thus, there is a possibility that the interface pressure produced by DLO provided continuous pressure which eventually reduces the spasticity in children with $\mathrm{CP}$ in current study.

\section{THE EFFECTS OF BODY DIMENSION ON ORTHOSIS INTERFACE PRESSURE}

It is believed that this is the first study that measures the interface pressure exerted by a Lycra base orthosis. Previously, the interface pressure was investigated on medical graded stocking, burn pressure garment, medical bandage and sports compression garment (BrophyWilliams et al. 2015; Hirai et al. 2012). Those medical compression products were used to improve venous return and arterial flow, reduces oedema, prevents scar development and even enhances athlete performance and recovery. The similarity between the available compressions garments include the production of graded interface pressure. The garment or fabric should exerted a higher pressure at distal end (i.e. small limb circumference) and the pressure should be decreasing at a proximal end of the limb (i.e. larger limb circumference) (Hui \& Ng 2001). Such principle has been used for many years and was found to be clinically efficient in treating lymphedema, scars, manage venous ulcer and for wound management (Hirai et al. 2012; King et al. 2012; Wang et al. 2010).

Current results demonstrated that the orthosis interface pressure level was not affected by the children's body dimension. For instance, the pressure level in Child 3 was found to be lower compared to Child 1. Despite the fact that Child 3 has the largest trunk dimension and Child 1 has the largest thigh dimension compared to the other children. The overall interface pressure was found to be the largest in Child 1 garment at trunk and pants during sitting, standing and STS. The identified interface pressure is extremely higher than what has been reported previously (Atiyeh et al. 2013; Chi et al. 2008; Lin et al. 2013; Liu et al. 2008; Troynikov et al. 2013). As mentioned earlier, the interface pressure exerted by burn compression garment, sports pressure garment, medical compression stocking and medical bandages is predicted by using reduction factors and guided by Leplace's Law (Aghajani et al. 2013; Liu et al. 2007; Yu et al. 2012). Up to date, no studies have yet determined the interface pressure level should be exerted by Lycra or any soft orthosis during application. Furthermore, there is no formula available in guiding the construction of Lycra based orthosis or to pre-determine the interface pressure that should be exerted these types of orthosis. Hence, in the current study, there were no reduction factors or prediction formula was used in construction of LO. Thus, it could be the reason why the currently identified pressure is higher than what has been reported previously.

The current findings show that the LO does not produce uniform and graded pressure over trunk and thighs segment. The interface pressure in other medical compression products is said to be influence by body curvature (i.e. concave or convex) and the limbs or segments circumference (Aiman et al. 2015; Lee \& Wigg 2013; Macintyre \& Baird 2006; Teng et al. 2006). Supposedly, in the current study, the interface pressure should be lower at top garment, as the trunk have larger dimension than pelvis-thighs. Whilst, in the current study, the tops garment (trunk) exerted higher interface pressure compared to pants (pelvic-thighs). Giele et al. (1998) evaluated the interface pressure of burn garment at 36 anatomical sites. The pressure was evaluated after donning using subcutaneous pressure measurement technique. Overall, greater rise in pressure was recorded over bony prominence area with a mean of $47.2 \mathrm{mmHg}$ and lowest pressure rise was over concave area with a mean of $6.2 \mathrm{mmHg}$. Based on their findings, Giele et al. (1997) suggested that the garment interface pressure are 
most likely to be greater over area with less soft tissues, between bony prominence and skin. Apparently, trunk has more rigid anatomical structure and less soft tissue padding compared to thighs. Thus, this could be the reason of why the current interface pressure is greater at trunk than at thighs segments. In addition, most of previous studies investigated the interface pressure on forearm, calf and ankle (Grenier et al. 2013; Hirai et al. 2012; Hui \& Ng 2001; Varan et al. 2013; Yildiz et al. 2007). Those segments have smaller dimension compared to trunk, pelvic-thighs. Hence it could be the reason why the current identified pressure are higher than the ones previously reported.

Next, the application of double layer and single layer of fabric to construct top garment straps may have contributed to higher interface pressure level over trunk than thighs region. The upper garment for LO is prepared with double layer, bilateral straps, meanwhile, the pants, was constructed using a single of Lycra fabric. Macintyre and Baird (2006) suggested that the application of multilayer fabric for burn garment could provide greater pressure to treat burn scars. Leung et al. (2010) in their pressure prediction model for burn garment found that the application of double layer fabric could help raising the interface pressure and provide custom fit burn compression garment. Hence, the application of double layer fabric at LO top garment straps could have raised the fabric tension and interface pressure level at trunk segment (Al Khaburi et al. 2012; Hirai et al. 2012).

It appears that some of the pressure identified in the current study are lower (e.g. 2 to $3 \mathrm{mmHg}$ ) than the sensor calibration values $(10-50 \mathrm{kPa} / 75-375 \mathrm{mmHg})$. This could be because, during sensor calibration, the applied pressure was controlled through the flat bladder. Meanwhile during experiment, as the child move, at uneven body surface, the fabric could have created minimal contact with the sensor and the child's skin, thus creating low interface pressure values than the calibration values. The orthosis, at the same time, maybe not tight enough, to create sufficient tension, to produce high interface pressure.

The sensor used in the current study is $9811 \mathrm{E}$ Tekscan $^{\mathrm{TM}}$ ultra-thin $(0.18 \mathrm{~mm})$ sensor. The same sensor has been used by other studies as it has sensitivity to detect low range interface pressure, flexible and not distorted by the skin (Ali et al. 2013, 2012; Eshraghi et al. 2012; Gholizadeh et al. 2014; Macintyre 2011). The sensitivity of the sensor however, are deteriorating with time. Thus, could be a reason why very low interface pressure was recorded (Luo et al. 1998; Macintyre 2011).

\section{GARMENT INTERFACE PRESSURE AT DIFFERENT POSTURE} AND ACTIVITY

Currently the recommended pressure used for burn compression garment, medical compression stocking and sports garment is ranging from 5 to $50 \mathrm{mmHg}$ (Anand et al. 2013; Kumar et al. 2013; Maklewska et al. 2006; Teng et al. 2006; Van Der Kerchove et al. 2005). But the current study recorded the highest pressure of $122 \mathrm{mmHg}$ over trunk and $120 \mathrm{mmHg}$ (groin) at thighs during sitting.
Most of the reported interface pressure was measured when patient or subject is in static position. Few studies have reported the differences of interface pressure medical bandages, compression garment at different postures and activities. Partsch (2005) found that the interface pressure of medical bandages is lower when his subject is in supine position, than in standing position. For the current orthosis, the interface pressure was found to be greater when the child is in sitting position (static) followed by standing and STS. The reason of that result was possibly because of the measurement taken during sitting position. Thus, the garment dimension is most likely fit the child's body the most during sitting position.

In active conditions, during STS could affect the interface pressure exerted by LO. There are significant changes in shape or size of different body parts during active movements (Lee et al. 2006). Mainly, at thighs region where limb circumferences are most likely changes when the child is in sitting, STS and standing posture. Thus, it leads to changes in the extension of the Lycra fabric. The changes on the Lycra fabric extension level may create a significant variation in the fabric tension forces, during STS. Consequently, it leads to various interface pressure level at different postures. This is because, according to the Laplace law, interface pressure is directly proportional to the tension (Taylor et al. 2013).

In addition, Wang et al. (2014) found that the interface pressure of elastic fabric changes as the body moves. After being exposed to repeated elongation and stretching, mainly more than $10 \%$ to $50 \%$, the fabric recovery behaviour and tension is decreasing (Mani \& Anbumani 2014) which may resulting in decreasing fabric interface pressure. Thus, it could possibly be the reason why during STS, the pressure is slightly lower than in sitting and standing position. Moreover, in the current study, the LO are exposed to repeated frontal plane motion, which also involved biaxial extension. The biaxial extension of fibres will stretch the yarn and caused inter-transfer of the elastic fabric loop. Therefore, the fabric fibre will slip to accommodate with the major distortion (i.e. repeated stretches and elongation) (Ito et al. 1995; Kumar et al 2013). Thus, reduces the elasticity and tension of the Lycra fabric fibres.

\section{CONCLUSION}

The current study manages to explore the pattern of interface pressure in fabric type of orthoses. It is believed this is the first study that had explored the interface pressure pattern of fabric types of orthosis. The LO interface pressure was found not graded and uniform at top and pants of LO. The interface pressure is higher at bigger circumference (trunk) and lower at smaller circumference (thighs). Nevertheless, the LO could benefit children with $\mathrm{CP}$, as included in current study, as it did change the child's STS duration and trunk control score. Yet, further study is needed to explore the technical and mechanical aspect the fabric and orthosis itself, to enhance the knowledge on how the orthosis works. Particularly in establishing a 
suitable formula or means to determine suitable interface pressure for fabric types of orthosis. It is hope that future study will explore the possibility of producing LO using three-dimensional constructive method so that the interface pressure can be determined earlier.

\section{ACKNOWLEDGEMENTS}

The authors would like to acknowledge the Malaysia UM/ MOHE/HIR grant (Project No: UM HIR (MOHE) D00001416001) for funding this study. Also special thanks to Malaysian Advocates for Cerebral Palsy (MyCP), Spastic Children's Association Of Selangor \& Federal Territory and University Malaya Medical Centre (UMMC) for supporting this study.

\section{REFERENCES}

Kumar, B., Das, A., Alagirusamy, R., Omeroglu, S., Ulku, S., $\mathrm{Wu}$, J., et al. 2013. Garment considerations, physiology and performance. The Engineering of Sport 36: 789-796.

Abd El-Kafy E.M. 2014. The clinical impact of orthotic correction of lower limb rotational deformities in children with cerebral palsy: A randomized controlled trial. Clinical Rehabilitation 28: 1004-1014.

Aghajani, M., Tehran, M.A., Asghar, A. \& Jeddi, A. 2013. Precise measurement of tension on curvature elastic shells. Journal of Engineered Fibers and Fabrics 8(1): 82-87.

Aiman, A.F., Salleh, M.N. \& Ismail, K.A. 2015. Pressure distribution from two different types of fabrics head garments with silon-LTS ${ }^{\circledR}$ face mask for hypertrophic burn scar treatment. 2nd International Conference on Biomedical Engineering (ICoBE). Penang, Malaysia. pp. 30-31.

Al Khaburi, J., Dehghani-Sanij, A.A., Nelson, E.A. \& Hutchinson, J. 2012. Effect of bandage thickness on interface pressure applied by compression bandage. Medical Engineering and Physics 34: 378-385.

Ali, S., Osman, N.A.A., Eshraghi, A., Gholizadeh, H. \& Abas, W.A.B.B.W. 2013. Interface pressure in transtibial socket during ascent and descent on stairs and its effect on patient satisfaction. Clinical Biomechanics 28(9): 994-999.

Ali, S., Osman, N.A.A., Mortaza, N., Eshraghi, A., Gholizadeh, H. \& Abas, W.A.B.B.W. 2012. Clinical investigation of the interface pressure in the trans-tibial socket with Dermo and Seal-In X5 liner during walking and their effect on patient satisfaction. Clinical Biomechanics 27(9): 943-948.

Anand, S.C., Govarthanam, K.K. \& Gazioglu, D. 2013. A study of the modelling and characterisation of compression garments for hypertrophic scarring after burns. Part 1: modelling of compression garments. Journal of the Textile Institute 104: 661-667.

Atiyeh, B.S., El-Khatib, M.A. \& Dibo, S.A. 2013. Pressure garment therapy (PGT) of burn scars: Evidence-based efficacy. Ann. Burns Fire Disasters 26: 205-212.

Bahramizadeh, M., Rassafiani, M., Aminian, G., Rashedi, V., Farmani, F. \& Mirbagheri, S.S. 2015. Effect of dynamic elastomeric fabric orthoses on postural control in children with cerebral palsy. Pediatric Physical Therapy 27: 349-354.

Brophy-Williams, N., Driller, M.W., Shing, C.M., Fell, J.W. \& Halson, S.L. 2015. Confounding compression: The effects of posture, sizing and garment type on measured interface pressure in sports compression clothing. Journal of Sports Science 33: 1403-1410.
Charlton, P.T. 2015. The use of orthoses in stroke rehabilitation. BJNN/Stroke Association Supplement. pp. 20-26.

Chi, C-F., Lin, C-H. \& Yang, H-S. 2008. The causal analysis of requested alterations for pressure garments. Journal of Burn Care \& Research 29: 965-974.

Duffield, R., Cannon, J. \& King, M. 2010. The effects of compression garments on recovery of muscle performance following high-intensity sprint and plyometric exercise. Journal of Science and Medicine in Sport 13: 136-140.

Elliott, C., Reid, S., Hamer, P., Alderson, J. \& Elliott, B. 2011 Lycra ${ }^{\circledR}$ arm splints improve movement fluency in children with cerebral palsy. Gait and Posture 33: 214-219.

Eshraghi, A., Osman, N.A.A., Karimi, M.T., Gholizadeh, H., Ali, S. \& Abas, W.A.B.W. 2012. Quantitative and qualitative comparison of a new prosthetic suspension system with two existing suspension systems for lower limb amputees. American Journal of Physical Medicine \& Rehabilitation 91(12): 1028-1038.

Gholizadeh, H., Osman, N.A.A., Eshraghi, A. \& Razak, N.A.A. 2014. Clinical implication of interface pressure for a new prosthetic suspension system. Biomedical Engineering Online 13(1): 89.

Giele, H., Liddiard, K., Booth, K. \& Wood, F. 1998. Anatomical variations in pressure generated by pressure garments. Plastic and Reconstructive Surgery 101: 399-406.

Giele, H.P., Liddiard, K., Currie, K. \& Wood, F.M. 1997. Direct measurement of cutaneous pressures generated by pressure garments. Burns 23: 137-141.

Grenier, E., Gehin, C., Lun, B. \& McAdams, E. 2013. Local effect of compression stockings on skin microcirculatory activity through the measurement of skin effective thermal conductivity. IEEE Engineering in Medicine and Biology Society Conference 2013: 1768-1771.

Higgins, T., Naughton, G.A. \& Burgess, D. 2009. Effects of wearing compression garments on physiological and performance measures in a simulated game-specific circuit for netball. Journal of Science and Medicine in Sport 12: 223-226.

Hirai, M., Koyama, A., Miyazaki, K., Iwata, H. \& Kominami, Y. 2012. Interface pressure and stiffness in different combinations of compression material. Phlebology 27: 82-89.

Hui, C.L. \& Ng, S.F. 2001. Pressure model of elastic fabric for producing pressure garments. Textile Research Journal 71: 275-279.

Ito, N., Inoue, M., Nakanishi, M. \& Niwa, M. 1995. The relation among the biaxial extension properties of girdle cloths and wearing comfort and clothing pressure of girdles. Japan Res. Assoc. Textile End Uses 36: 102-108.

Jin, Z.M., Ou, Y., Xu, N. \& Yan, Y.X. 2013. Pressure analysis on medical compression hosiery and property research of lycra/ nylon double wrapped yarn. Advanced Materials Research 821-822: 215-218.

King, M., Deveaux, A., White, H. \& Rayson, D. 2012. Compression garments versus compression bandaging in decongestive lymphatic therapy for breast cancer-related lymphedema: A randomized controlled trial. Supportive Care in Cancer 20: 1031-1036.

Lee, A.J., Dale, J.J., Ruckley, C.V., Gibson, B., Prescott, R.J. \& Brown, D. 2006. Compression therapy: Effects of posture and application techniques on initial pressures delivered by bandages of different physical properties. European Journal of Vascular and Endovascular Surgery 31: 542-552. 
Lee, N. \& Wigg, J. 2013. Getting the right fit: Made-to-measure garments for lymphedema management. British Journal of Community Nursing 18: S28-S33.

Leung, W.Y., Yuen, D.W., Ng, S.P. \& Shi, S.Q. 2010. Pressure prediction model for compression garment design. Journal of Burn Care \& Research 31: 716-727.

Lin, S-H., Lin, J-M., Chu, C-L., Wu, Y-S., Chao, Y-J., Chan, W-P., Choy, C-S. \& Leung, T-K. 2013. Design, manufacture, mechanical testing and clinical/MRI assessment of the medical elastic compression stockings, base on Taiwanese's leg size. Journal of Textile Science \& Engineering 4: 1-9.

Liu, R., Lao, T.T., Kwok, Y.L., Li, Y. \& Ying, M.T.C 2008. Effects of graduated compression stockings with different pressure profiles on lower-limb venous structures and haemodynamics. Advances in Therapy 25: 465-478.

Liu, W.Y., Zaino, C.A. \& McCoy, S.W. 2007. Anticipatory postural adjustments in children with cerebral palsy and children with typical development. Pediatric Physical Therapy 19(3): 188-195.

Luo, Z.P., Berglund, L.J. \& An, K.N. 1998. Validation of F-Scan pressure sensor system: A technical note. Journal of Rehabilitation Research and Development 35(2): 186-191.

Macintyre, L. 2011. New calibration method for I-scan sensors to enable the precise measurement of pressures delivered by 'pressure garments'. Burns 37(7): 1174-1181.

Macintyre, L. \& Baird, M. 2006. Pressure garments for use in the treatment of hypertrophic scars - A review of the problems associated with their use. Burns 32: 10-15.

Maklewska, E., Nawrocki, A., Ledwoń, J. \& Kowalski, K. 2006. Modelling and designing of knitted products used in compressive therapy. Fibres and Textiles in Eastern Europe 14: 111-113.

Mani, S. \& Anbumani, N. 2014. Dynamic elastic behaviour of cotton and cotton/spandex knitted fabric. Journal of Engineered Fibers \& Fabrics 9: 93-100.

Matthews, M., Blandford, S., Marsden, J. \& Freeman, J. 2016. The use of dynamic elastomeric fabric orthosis suits as an orthotic intervention in the management of children with neuropathic onset scoliosis: A retrospective audit of routine clinical case notes. Scoliosis and Spinal Disorders 11: 14.

Mohapatra, J., Verma, S. \& Valvalruati, M. 2015. Effect of soft hand splint (lycra) for stereotypic hand behaviour in children with dystonia: Case report. Journal of Pediatrics \& Neonatal Care 2: 3-6.

Morris, C., Bowers, R., Ross, K., Stevens, P. \& Phillips, D. 2011. Orthotic management of cerebral palsy: Recommendations from a consensus conference. NeuroRehabilitation 28: $37-46$.

Partsch, H. 2005. The static stiffness index: A simple method to assess the elastic property of compression material in vivo. Dermatologic Surgery 31: 625-630.

Rennie, D.J., Attfield, S.F., Morton, R.E., Polak, F.J. \& Nicholson, J. 2000. An evaluation of lycra garments in the lower limb using 3-D gait analysis and functional assessment (PEDI). Gait and Posture 12: 1-6.

Sau-Fun, N., Chi-Leung, H. \& Lai-Fan, W. 2011. Development of medical garments and apparel for the elderly and the disabled. Textile Progress 43: 235-285.
Taylor, P., Kumar, B., Das, A. \& Alagirusamy, R. 2013. An approach to examine dynamic behavior of medical compression bandage. Journal of the Textile Institute 104: $37-41$.

Teng, T.L. \& Chou, K.T. 2006. The measurement and analysis of the pressure generated by burn garments. Journal of Medical and Biological Engineering 26: 155-159.

Troynikov, O., Wardiningsih, W., Koptug, A., Watson, C. \& Oggiano, L. 2013. Influence of material properties and garment composition on pressure generated by sport compression garments. Procedia Engineering 60: 157-162.

Van Den Kerckhove, E., Stappaerts, K., Fieuws, S., Laperre, J., Massage, P., Flour, M. \& Boeckx, W. 2005. The assessment of erythema and thickness on burn related scars during pressure garment therapy as a preventive measure for hypertrophic scarring. Burns 31: 696-702.

Varan, N.Y., Gürsoy, N.C., King, M.W. \& Hauser, P.J. 2013. Novel elastomeric fabrics for burn pressure garments using silver antimicrobial agents. Journal of Textile \& Apparel 23: $38-42$.

Wang, L., Felder, M. \& Cai, J.Y. 2011. Study of properties of medical compression garment fabrics. Journal of Fiber Bioengineering and Informatics 4: 15-22.

Wang, P., McLaren, J., Leong, K.F. \& Des Ouches, P.J. 2013. A pilot study: Evaluations of compression garment performance via muscle activation tests. Procedia Engineering 60: 361-366.

Wang, Y. \& Zhang, P. 2013. The effect of physical-mechanical properties on dynamic pressure of compression garment International Journal of Clothing Science and Technology 25: 131-144.

Wang, Y., Zhang, P. \& Zhang, Y. 2014. Experimental investigation the dynamic pressure attenuation of elastic fabric for compression garment. Textile Research Journal 84: 572-582.

Wang, Y., Zhang, P., Feng, X. \& Yao, Y. 2010. New method for investigating the dynamic pressure behavior of compression garment. International Journal of Clothing Science and Technology 22: 374-383.

Yildiz, N. 2007. A novel technique to determine pressure in pressure garments for hypertrophic burn scars and comfort properties. Burns 33: 59-64.

Yu, A., Yick, K.L., Ng, S.P. \& Yip, J. 2012. Prediction of fabric tension and pressure decay for the development of pressure therapy gloves. Textile Research Journal 83: 269-287.

Department of Biomedical Engineering

Faculty of Engineering, University of Malaya

50603 Kuala Lumpur, Federal Territory

Malaysia

*Corresponding author; email: azuan@um.edu.my

Received: 12 January 2016

Accepted: 11 August 2017 
